\title{
Use of patients' classification instruments: analysis of the brazilian production of knowledge
}

\author{
UTILIZAÇÃO DE INSTRUMENTOS DE CLASSIFICAÇÃO DE PACIENTES: ANÁLISE DA \\ PRODUÇÃO DO CONHECIMENTO BRASILEIRA
}

\section{UTILIZACIÓN DE INSTRUMENTOS DE CLASIFICACIÓN DE PACIENTES: ANÁLISIS DE LA PRODUCCIÓN DEL CONOCIMIENTO BRASILEÑO}

\author{
Sonia Portella de Abreu¹, Daniele Alcalá Pompeo², Márcia Galan Perroca²
}

\begin{abstract}
Objective: To analyze the production of scientific knowledge about the use of patients' classification instruments in care and management practice in Brazil. Methods: Integrative literature review with databases search in: Latin American and Caribbean Literature on Health Sciences (LILACS), Medical Literature Analysis and Retrieval System on-line (MEDLINE), Cumulative Index to Nursing and Allied Health Literature (CINAHL) and SCOPUS, between January 2002 through December 2013. Results: 1,194 studies were found, 31 met the inclusion criteria. We observed a higher number of studies in the category care plans and workload $(n=15)$, followed by the category evaluation of psychometric properties $(n=14)$. Conclusion: Brazilian knowledge production has not yet investigated some purposes of using instruments for classifying patients in professional nursing practice. The identification of unexplored areas can guide future research on the topic.
\end{abstract}

\section{DESCRIPTORS}

Patients

Classification

Nursing care

Workload

Nursing assessment

Review

\section{RESUMO}

Objetivo: Analisar a produção do conhecimento científico sobre a utilização de instrumentos de classificação de pacientes na prática assistencial e gerencial no Brasil. Método: Revisão integrativa da literatura com consulta nas bases de dados: Literatura Latino-Americana e do Caribe em Ciências da Saúde (LILACS), Medical Literature Analysis and Retrieval System on-line (MEDLINE), Cumulative Index to Nursing and Allied Health Literature (CINAHL) e SCOPUS, relativas ao período de janeiro de 2002 a dezembro de 2013. Resultados: Das 1.194 publicações encontradas, 31 atenderam aos critérios de seleção. Observou-se maior número de artigos na categoria perfil assistencial e carga de trabalho $(n=15)$, seguidos da categoria avaliação das propriedades psicométricas ( $n=14)$. Conclusão: $A$ produção nacional ainda não investigou algumas finalidades de utilização de instrumentos de classificação de pacientes na prática profissional do enfermeiro. A identificação de áreas ainda inexploradas poderá nortear futuras investigações sobre a temática.

\section{DESCRITORES \\ Pacientes \\ Classificação \\ Cuidados de enfermagem \\ Carga de trabalho \\ Avaliação em enfermagem \\ Revisão}

\section{RESUMEN}

Objetivo: Analizar la producción del conocimiento científico acerca de la utilización de instrumentos de clasificación de pacientes en la práctica asistencial y de gestión en Brasil. Método: Revisión integradora de la literatura con consulta a las bases de datos: Literatura Latinoamericana y del Caribe en Ciencias de la Salud (LILACS), Medical Literature Analysis and Retrieval System online (MEDLINE), Cumulative Index to Nursing and Allied Health Literature (CINAHL) y SCOPUS, relativas al período de enero de 2002 a diciembre de 2013. Resultados: De las 1.194 publicaciones encontradas, 31 atendieron a los criterios de selección. Se observó una mayor cantidad de artículos en la categoría perfil asistencial y carga laboral $(n=15)$, seguidos de la categoría evaluación de las propiedades psicométricas $(n=14)$. Conclusión: La producción nacional todavía no ha investigado algunas finalidades de utilización de instrumentos de clasificación de pacientes en la práctica profesional del enfermero. La identificación de áreas aún no exploradas podrá orientar futuras investigaciones acerca de la temática.

\section{DESCRIPTORES \\ Pacientes \\ Clasificación \\ Atención de enfermería \\ Carga de trabajo \\ Evaluación en enfermería \\ Revisión}

${ }^{1}$ Masters' student, Graduate Program in Nursing, Medical School of São José do Rio Preto, São José do Rio Preto, SP, Brazil. ${ }^{2}$ PhD professor, Departament of Specialized Nursing, Medical School of São José do Rio Preto, São José do Rio Preto, SP, Brazil. ${ }^{3}$ PhD professor, Departament of Specialized Nursing, Medical School of São José do Rio Preto, São José do Rio Preto, SP, Brazil. 


\section{INTRODUCTION}

The evidence-based practice (EBP) aims to increase the quality of care and safety of patients, and is considered one of the five core competencies of the health professional ${ }^{(1)}$. Including the use of measurement scales for performing EBP and obtaining reliable results have been increasingly frequent in Nursing. Among them, the patients classification instrument ( $\mathrm{PCl})$ is highlighted as a guide to decision-making process in management of care ${ }^{(2)}$.

$\mathrm{PCl}$ identifies the demand for care of patients in relation to nursing, allowing monitoring of the workload of the team and its quantitative and qualitative adjustment when necessary. Based upon these data, nurses working in care or managerial functions may further characterize the care planning for patients and adjust their allocation units; planning more effectively care and discharge; supporting the achievement of quality in care and plan care costs. The use of this instrument strengthens the negotiation process for obtaining additional personnel in situations of relocating teams ${ }^{(3-4)}$.

Since the late 90s, PCls have been developed and validated for use in various specialties in Brazil. Among them we highlight those addressed for adult patients ${ }^{(2,5-6)}$, that have been most used by hospitals. There are also available $\mathrm{PCls}$ for use in areas such as Neonatology ${ }^{(7)}$, Pediatrics $^{(8)}$ and Psychiatry ${ }^{(9-10)}$. Despite the existence of PCls to suit different types of clients, their application in daily nursing practice is not yet a reality in many institutions ${ }^{(2)}$.

The importance of the implementation of $\mathrm{PCl}$ in professional practice was recognized by the Brazilian Federal Nursing Council (COFEN) through Resolution 293/04 ${ }^{(11)}$. According to this document, the calculation of nursing staff must be grounded in the $\mathrm{PCl}$ and the proportion of the elements of the nursing team, distributed in percentage determined in different types of care: minimal or selfcare, intermediate, semi-intensive and intensive care.

This study is part of a broader research, which aims to investigate how PCls have been used in hospitals in the State of Sao Paulo. At this early stage, we seek to know the paths of Brazilian production of knowledge on the subject in a 12-year period, in order to identify unexplored areas and guide future investigations. Thus, this study aims to analyze the production of knowledge about the use of $\mathrm{PCl}$ in care and management practice in Brazil.

\section{METHOD}

This is an integrative literature review which considered the following steps: identification of the research question, literature search, categorization and assessment of studies, interpretation of results and synthesis of knowledge ${ }^{(12)}$. The guiding question was: With what purpose have $\mathrm{PCl}$ been used in Brazilian literature?
To develop this study, the following databases were chosen: Latin American and Caribbean Literature on Health Sciences (LILACS), Medical Literature Analysis and Retrieval System on-line (MEDLINE), Cumulative Index to Nursing and Allied Health Literature (CINAHL) and SCOPUS. These databases were selected because they represent the most relevant publications of Nursing in health care and on the subject. Additional searches were also conducted in a nursing database (BDENF), Caribbean Literature on Health Sciences (MedCaribe) and at the virtual Scientific library Electronic Library Online (SCIELO).

The inclusion criteria were: studies published from January 2002 to December 2013, in Portuguese, English and Spanish. We excluded studies that did not explore some form of application of $\mathrm{PCl}$ in professional practice (theoretical) and that focused exclusively on its use for calculating personnel. It is important to emphasize that the application of this instrument allows the identification of the workload, which is one of the variables to be evaluated in the method of estimation of the nursing staff.

The sample size calculation used was snowball (snowball sampling), which uses referral chains, a kind of network to extract the maximum of information on all its members. In other words, people from a target population selected by the researcher indicate, through their contacts, other individuals to complete the sample ${ }^{(13)}$. In this research, new studies were identified by checking the references of studies that met the inclusion criteria.

Data collection was conducted from 07/10/2013 to $07 / 02 / 2014$ by two researchers independently (agreement level of 100\%). In order to search in LILACS database, controlled descriptors of the Regional Library of Medicine (BIREME) and Health Sciences Descriptors (DECS) were used; in MEDLINE, CINAHL, and SCOPUS the applied descriptors were not controlled (Figure 1).

The data extracted from included studies were organized, categorized and summarized using the Matrix method $^{(14)}$. The Matrix topics were structured before data extraction and used as guides for analysis. It included information about authorship and source of study setting, objective and study design, main results, conclusions and recommendations.

In order to assess researches quality, the Research Appraisal Checklist (RAC) ${ }^{(15)}$ was used, a scale designed to quantitative research, which shows a Cronbach's alpha of 0.91 , good construct validity and recommended in the literature ${ }^{(16)}$. It consists of 51 assessment criteria grouped in 10 categories, such as: Title, Abstract, Methodology, Data Analysis, Discussion and Form \& Style. Each criterion may score from 1 (Not Met) to 6 (Fully Met). The scores allowed the evaluation of strengths and limitations of the studies, classifying them into superior (205-306), average (103-204) and below average (0-102).
Use of patients' classification instruments: analysis of the brazilian production of knowledge Abreu SP, PompeoDA, Perroca MG 


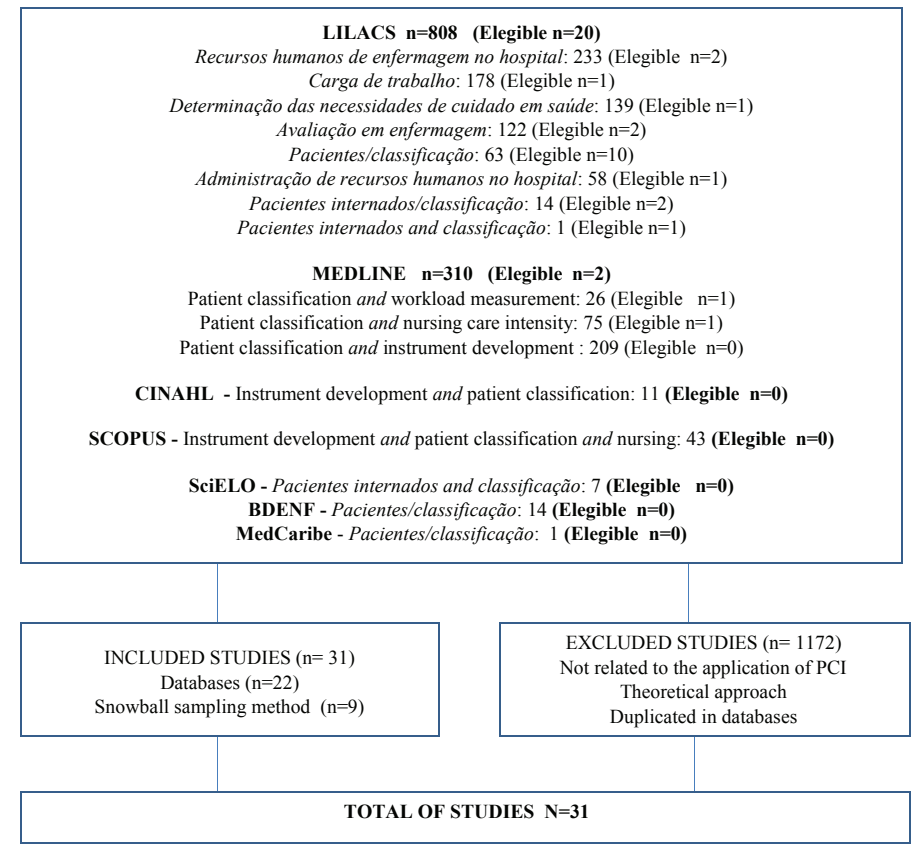

Figure 1 - Flowchart of identification, exclusion and selection os studies.

\section{RESULTS}

From the 31 studies analyzed, ten were published between 2002 and 2005, eight between 2006 and 2009 and thirteen from 2010 to 2013. The state of Sao Paulo accounted for 23 studies, four studies were from Rio Grande do Sul and one study was from Parana and another one from Piaui. Two studies in the international literature were found.
The studies were classified into three categories according to purpose of application: Psychometric Properties Evaluation (PPE; $n=14$ ), care profile and workload $(W L ; n=15)$ and care planning $(C P ; n=2)$. In the category PPE, the tests performed with the instruments to assess validity and reliability were included in various specialties $(n=8)$ : Pediatrics $(n=3)$, Psychiatry $(n=2)$ and Neonatology $(n=1)$ (Table 1$)$.

Table 1 - Summary of the characteristics of the studies in the category Psychometric Properties Evaluation - São José do Rio Preto, $2014(\mathrm{n}=14)$

\begin{tabular}{|c|c|c|c|}
\hline Characteristic assessed Evidence & Method & Instrument (CPI) & Results and Evidence \\
\hline Inter-rater reliability ${ }^{(8,10,17-20)}$ & $\begin{array}{l}\text { Kappa Coefficient }{ }^{(8,10,18-20)} \\
\text { Pearson Correlation }{ }^{(17,20)} \\
\text { Between nurses }{ }^{(17-18)} \\
\text { Nurses, technician and physician } \\
\text { versus Pediatrics PCI } \\
(19)\end{array}$ & $\begin{array}{l}\text { Perroca (original) }{ }^{(17-18)} \\
\text { Psychiatry }^{(10)} \\
\text { Pediatrics }^{(8,19)} \\
\text { Perroca (new version) })^{20}\end{array}$ & $\begin{array}{l}\mathrm{K}=0.68-0.90^{(18)} ; 0.17-0.76^{(10)} \\
0.69-0.84^{(19)} \\
0.41-0.74 \text { and } \geq 0.75^{(8)} \mathrm{r}=0.87- \\
0.95^{(17)} \alpha=0.87 ; \mathrm{CCI}=0.89-0.90^{(20)}\end{array}$ \\
\hline $\begin{array}{l}\text { Internal reliability and users' } \\
\text { opinions }(21)\end{array}$ & $\begin{array}{l}\text { Cronbach' alpha }{ }^{(21)} \\
\text { Spearman Correlation }^{(21)}\end{array}$ & $\begin{array}{l}\text { Perroca } \\
\text { original }^{(21)}\end{array}$ & $\begin{array}{l}\alpha=0.94 ; \mathrm{rs}=0.08 \text { to } 0.87^{(21)} \text { Satis- } \\
\text { fied users; tendency to underesti- } \\
\text { mate the care category }{ }^{(21)} \text {. }\end{array}$ \\
\hline Content validity $(2,7-9,22)$ & $\begin{array}{l}\text { Delphi technic }{ }^{(2,7-9,22)} \\
\text { Agreement level } \geq \\
70 \%(2,7-9,22)\end{array}$ & $\begin{array}{l}\text { Neonatology } \\
\text { Psychiatry }^{(7)} \text { Pediatrics }^{(8,22)} \\
\text { Perroca new version }^{(2)}\end{array}$ & 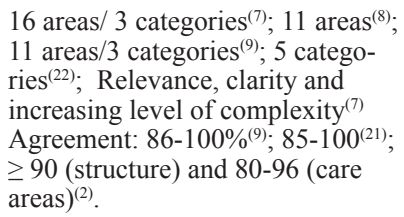 \\
\hline Agreement between instruments ${ }^{(24)}$ & Spearman and Weighted Kappa ${ }^{(24)}$ & $\begin{array}{l}\text { Perroca original and } \\
\text { Swedish } \text { PCI }^{(24)}\end{array}$ & $\begin{array}{l}\mathrm{r}=0.83 \text { (total score) and } 0,80 \text { (clas- } \\
\text { sification) Kw: } 0.60(95 \% \mathrm{CI} ; 0.5 \\
-0.71)^{(24)}\end{array}$ \\
\hline Predictive ability ${ }^{(6,20)}$ & Ordinal Logistic Regression ${ }^{(6,20)}$ & $\begin{array}{l}\text { Perroca original } \\
\text { Perroca new version }^{(20)}\end{array}$ & Success rate: $99.8 \% \%^{(6)} ; 99.6^{(20)}$ \\
\hline
\end{tabular}

K: kappa; WK: Weighted kappa; r: Pearson correlation; $\alpha$ : Cronbach'alpha; ICC: intraclass correlation coefficient; Cl: confidence interval. 
Out of the 15 studies investigated in the category WL, eight were conducted in medical-surgical units and seven in specialized units (hemodynamics, emergency room, post-anesthesia recovery, pediatrics, psychiatry, and geriatrics). To identify the demand for patient care in relation to the Nursing, $\mathrm{PCl}$ were used in the original ${ }^{(6)}$, new version $^{(2)}(n=9)$, adult patients ${ }^{(5)}(n=4)$, pediatrics ${ }^{(8)}(n=1)$ and psychiatry ${ }^{(9-10)}(n=1)$. (Table 2).

Table 2 - Summary of the characteristics of the studies in the Care Profile and Workload category - Sao José do Rio Preto, 2014 (n=15)

\begin{tabular}{|c|c|c|c|}
\hline Instrument & Method & Setting & Results and Evidence \\
\hline et al. ${ }^{(5,25-27)}$ & $\begin{array}{l}\text { PCI and nursing notes (admis- } \\
\text { sion, through the admission and } \\
\text { discharge)- } \\
19 \text { nurses }^{(25)} \\
\text { Daily classification }^{(5,26-27)}\end{array}$ & $\begin{array}{l}4 \text { Wards }-\mathrm{N}=74^{(25)} \text {; } \\
9 \text { Wards- } 31.081 \text { assessments }^{(5)} \\
1 \text { Ward }-1.080 \text { assessments }^{(27)} \\
\text { ER }-1.228 \text { assessment }^{(26)}\end{array}$ & $\begin{array}{l}\text { Minimal care for the majority } \\
\text { (medical and surgical clinics), high } \\
\text { dependency } \\
\text { (pediatrics) and intermediate } \\
\text { (rooming) }^{(5)} \\
\text { Predominance minimal care } \\
\text { intermediate }^{(25)} \text {; High dependence } \\
\text { Treatment of patients who do not } \\
\text { require hospitalization or observa- } \\
\text { tion }^{(26)}\end{array}$ \\
\hline Perroca original version ${ }^{(28-35)}$ & $\begin{array}{l}\text { Classification in } 48 \mathrm{~h}, 5^{\text {th }}, 10 \text { th } \\
\text { and } 15 \text { th day in hospital }{ }^{(28)} \\
\text { Daily classification }{ }^{(29-34)} \\
\text { Three classifications: admis- } \\
\text { sions, average length of hospital } \\
\text { stay } \\
\text { and discharge }{ }^{(35)}\end{array}$ & $\begin{array}{l}2 \text { Wards }-\mathrm{n}=31 \text { e } \mathrm{n}=35^{(28)} ; 1 \\
\text { Ward - } 968 \text { assessments } \\
14 \text { Wards }-\mathrm{N}=318^{(20)} \mathrm{Hemody-}^{(29)} \\
\text { namic - } \\
\mathrm{N}=167^{(31)} \\
4 \text { Wards - } 40 \text { surgical and medi- } \\
\text { cal patients - } 642 \text { assessments } \\
\text { PAR - N=402) } \\
4 \text { Wards - } 2291 \text { classifica- } \\
\text { tions }^{(34)} \text { Geriatric Ward - } 483_{\text {assessments }^{(35)}}\end{array}$ & $\begin{array}{l}\text { Predominance of care patients: } \\
\text { minimum }{ }^{(28-30,34)} \text {; intermediate }{ }^{(31,35)} \\
\text { Existence of semi-intensive patients } \\
(28,29) \text { and intensive }{ }^{(28,30,34)} \text { in Wards } \\
\text { Demand the same attention in } \\
\text { admission and discharge }{ }^{(28)} \\
\text { Patients in the clinical care } \\
\text { category identified on admission; } \\
\text { variation between surgical care } \\
\text { categories } \\
\text { Significant relation between degree } \\
\text { of dependency and the ASA clas- } \\
\text { sification scale } \\
\text { Insufficient hours to meet demand } \\
\text { (34) } \\
\text { Associated age group (80-100 } \\
\text { years) and intermediate and semi- } \\
\text { intensive care } \\
\text { (35) }\end{array}$ \\
\hline Psychiatry $^{(36-37)}$ & Daily classification $^{(35-37)}$ & $\begin{array}{l}2 \text { psychiatry Wards - } \\
\mathrm{N}=43^{(36)}\end{array}$ & $\begin{array}{l}\text { Predominant category of discreet } \\
\text { care }^{(36-37)} \text { without the need for insti- } \\
\text { tutionalization }^{(37)}\end{array}$ \\
\hline Pediatrics $^{(38)}$ & Daily classification $^{(38)}$ & $\begin{array}{l}3 \text { psychiatry Wards }-\mathrm{N}=105^{(37)} \\
\text { Pediatric Ward }-\mathrm{N}=40^{(38)}\end{array}$ & $\begin{array}{l}\text { Insufficient hours to assistance and } \\
\text { meet the needs of patients }{ }^{(37)} \\
\text { Most high dependency }{ }^{(38)}\end{array}$ \\
\hline
\end{tabular}

ER- Emergency room; PAR - Post-anesthesia Recovery.

In the third category, care planning (CP) (Table 3), two studies were included ${ }^{(38-39)}$, both applying $\mathrm{PCl}$ in the original version. The first ${ }^{(39)}$ used the instrument to analyze the predisposition to pressure ulcers and the other ${ }^{(40)}$ to guide the planning of discharge.

Table 3 - Summary of the characteristics of the studies in the category Care planning - São José do Rio Preto, 2014 (n=2)

\begin{tabular}{|c|c|c|c|}
\hline Instrument & Method & Setting & Results and Evidence \\
\hline Perroca & $\begin{array}{l}\text { PCI classification and application } \\
\text { of the Braden Scale - every }\end{array}$ & 2 Wards - $\mathrm{N}=40^{(39)}$ & $\begin{array}{l}\text { Predominance of patients in inter- } \\
\text { mediate, semi-intensive care and } \\
\text { high-risk care }{ }^{(39)}\end{array}$ \\
\hline \multirow[t]{3}{*}{ Original version ${ }^{(39-40)}$} & 48 h until discharge $\mathrm{e}^{(39)}$ & & $\begin{array}{l}\text { No regular use of instruments such } \\
\text { as the Braden scale and PCI }{ }^{(39)}\end{array}$ \\
\hline & & 2 Wards $-\mathrm{N}=50^{(40)}$ & $\begin{array}{l}\text { Increase of } 71.3 \% \text { in identifying } \\
\text { the needs of care through the use of } \\
\text { the instrument }{ }^{(40)}\end{array}$ \\
\hline & $\begin{array}{l}\text { Discharge orientation before and } \\
\text { after the application of PCI }{ }^{(40)}\end{array}$ & & $\begin{array}{l}\text { Recommends the use of PCI to } \\
\text { guide nursing discharge planning }\end{array}$ \\
\hline
\end{tabular}

According to the RAC, 21 studies were considered superior (PPA 11, WL 9 and CP 1) and 10 average (PPA $3, \mathrm{WL} 6, \mathrm{CP} 1)$. No studies were found below the average. The average score was $252.5(\mathrm{SD}=32.8$, range= 193-287). The area that least scored was methodology $79.5 / 102(77.9 \%)$ due to very low sample, no presentation of data reliability and validity of the instruments used and inadequate design and statistical analysis of the research question.

\section{DISCUSSION}

Through this research it is possible to identify the panorama of Brazilian scientific production related to the use of $\mathrm{PCls}$ in care and management practice in Brazil from 2002 to 2013. Thirty-one eligible studies were found, verifying an average of two to three publications per year and gradually increase over the years. A predominance of productions coming from the Southeast regions $(n=23)$ and 
also in public institutions were observed, especially those focused on education, which were the most published ones.

Care profile and workload category had the highest number of studies $(n=15)$, demonstrating the concern of researchers in knowing their clientele and workload. Conducting situational diagnosis of inpatient unit or service involving its philosophy, objectives, characterization of patients and health care proposals have been highlighted in the literature ${ }^{(41)}$. Studies describing the percentage of agreement between the raters after the training program for the use of $\mathrm{PCl}$ were not found. The assessment that all nurses interpreted the instrument in the same way, with levels of agreement $\geq 80 \%$, ensures the reliability of the data generated ${ }^{(2)}$.

Most studies were descriptive-exploratory and crosssectional, highlighting the need to improve the allocation of patients to different degrees of care complexity and the importance of using PCls for reassessment of staff. Such studies allow individualized identification of needs of patient care and the demand for care in relation to staff (care category). Above all, they make it possible to estimate and adjust the volume of the proposed work to the availability of nursing staff (Quanti-qualitative adequation); recruiting and selecting nursing staff in accordance with the care profile from the patients and further strengthen the argument regarding the need for additional staff( ${ }^{(3-4)}$.

As regards the application of $\mathrm{PCl}$ to obtain care profiles, a higher number of studies that used the original instrument was observed ${ }^{(6)}$, followed by the $\mathrm{PCl}$ in adult patients ${ }^{(5)}$. Probably this can be explained as they were built and made available for longer and thus being well known by the scientific community. There was unanimity regarding the use of $\mathrm{PCl}$ to assist the planning and management of nursing staff.

A certain concern in assessing the psychometric properties of the proposed $\mathrm{PCl}$ (category 1: 14/31) to obtain reliable and valid results to be used in professional practice was observed. To become reliable, psychometric measure is conditional to validation. Validating an instrument requires the study of two main features: the validity and reliability ${ }^{(42)}$. The validity consists in knowing whether the instrument actually measures what it proposes, while reliability refers to the degree of accuracy, in other words, how their results precisely reflect the actual measurements of the attribute investigated ${ }^{(43)}$.

The researchers used diverse tests to prove reliability and validity of the instruments: inter-rater reliability $(8,10,17-20)$, predictive ability ${ }^{(6,20)}$, users' opinion ${ }^{(21)}$, content validity ${ }^{(2,7-9,22)}$ and construct validity ${ }^{(10,20-21,23)}$. The original $\mathrm{PCl}$ and its new version were the most subjected to a validation process $^{(2,6,20-21,23-24)}$. The psychometric properties of the $\mathrm{PCl}$ allows the generation of legitimate and reliable data, allowing its use in clinical practice to measure the workload of the nursing staff and to guide management decisions ${ }^{(20)}$.

The low number of published studies in the category Care Planning in Nursing ${ }^{(39-40)}$ demonstrates that, although the PCls are applied for classifying the complexity of patient care in the wards the results seem to be used and reported in the literature to support the management of care in its many stages.

The application of RAC assessed the quality of 31 published studies which were considered superior (67.7\%) and average (32.3\%). The major weaknesses of the studies were methodological limitations (77.9\%), being found scores higher than other studies ${ }^{(16)}$, applying the same scale (67.3\%).

Although the use of a $\mathrm{PCl}$ is recommended by COFEN ${ }^{(11)}$ (Brazilian Federal Nursing Council) as an important management instrument, there is little dissemination in the literature regarding the work developed in hospitals. It is noteworthy that the use of $\mathrm{PCl}$ for the investigation was chosen for purposes of estimating individuals to understand that this category is clearly demonstrated in the daily life of managers and is the subject of several studies.

The findings of this review showed that the Brazilian literature on the use of $\mathrm{PCl}$ is still restricted to the identification of the demand for patient care in relation to nursing and more focused on the quanti-qualitative staff working on wards. It was evidenced that there are so many unexplored areas, among them the use for managing costs, improving the quality of care provided, productivity and worker health.

In Sweden, in $1997^{(44)}$ there was concern in determining the costs of nursing care and related it to the needs of staff for caring. The application of PCl called Zebra allowed the calculation of the cost of nursing staff per patient/day replacing the standard fixed costs.

Finland has been highlighted by the construction, validation and use of $\mathrm{PCI}$ Rafaela for various purposes, with several published studies. Among them, a study that aimed to investigate the feasibility of this instrument to measure the utilization of nursing staff in the process of care and its associated costs, as well as productivity is emphasized ${ }^{(45)}$. Another study used it to assist in the process of decision making on allocation of staff based on evidence ${ }^{(46)}$. More recently, a research with 877 nurses $^{(47)}$ analyzed whether the overload of work associated with patient was related to sick leave and lost work days.

This review presents limitations for not including universities' productions (theses and dissertations) indexed in databases, conference proceedings and unpublished material in digital databases.

It is expected that the critical review of the studies can incorporate evidence for improving clinical practice and assist in the process of decision-making by nurse managers.

\section{CONCLUSION}

Brazilian production of knowledge has not yet investigated some outcomes of using $\mathrm{PCl}$ in professional nursing practice. The identification of unexplored areas can guide future research on the topic. 


\section{REFERENCES}

1. Boström AM, Ehrenberg A, Gustavsson JP, Wallin L, Rudman A. Factors associated with evidence-based practice among registered nurses in Sweden: a national cross-sectional study. BMC Health Serv Res. 2013;13:165.

2. Perroca MG. Development and content validity of the new version of a patient classification instrument. Rev Latino Am Enfermagem. 2011;19(1):58-66.

3. De Groot HA. Patient classification system evaluation: part two, system selection and implementation. J Nurs Adm. 1989;19(7):24-30.

4. Malloch K, Conovaloff A. Patient classifications systems. Part 1: the third generation. J Nurs Adm. 1999;29(7-8):49-56.

5. Fugulin FMT, Gaidzinski RR, Kurcgant P. Sistema de classificação de pacientes: identificação do perfil assistencial dos pacientes das unidades de internação do HU-USP. Rev Latino Am Enfermagem. 2005;13(1):72-8.

6. Perroca MG, Gaidzinski RR. Avaliação da capacidade preditiva e formato final de um instrumento para classificação de pacientes. Acta Paul Enferm. 2003;16(2):56-66.

7. Bochembuzio L, Gaidzinski RR. Instrumento para classificação de recém-nascidos de acordo com o grau de dependência de cuidados de enfermagem. Acta Paul Enferm. 2005;18(4):382-9.

8. Dini AP, Fugulin FMT, Veríssimo MLOR, Guirardello EB. Construção e validação de um instrumento de classificação de pacientes pediátricos. Acta Paul Enferm. 2013;26(2):144-9.

9. Martins PASF, Forcella HT. Sistema de classificação de pacientes na especialidade enfermagem psiquiátrica. Acta Paul Enferm. 2006;19(1):62-9.

10. Martins PASF, Arantes EC, Forcella HT. Sistema de classificação de pacientes na Enfermagem Psiquiátrica: validação clínica. Rev Esc Enferm USP. 2008;42(2):233-41.

11. Conselho Federal de Enfermagem. Resolução n.293/04. Fixa e estabelece parâmetros para dimensionamento do quadro de profissionais de enfermagem nas unidades assistenciais das instituições de saúde e assemelhados [Internet]. São Paulo: COREN-SP; 2004 [citado 2013 jun. 10]. Disponível em: http://novo.portalcofen.gov.br/resoluocofen-2932004_4329.html

12. Whittemore $R$, Knafl $K$. The integrative review: updated methodology. J Adv Nurs. 2005;52(5):546-53.

13. Goodman L. Snowball sampling. Ann Math Stat. 1961;32:148-70.

14. Garrad J. Health sciences literature review made easy: the matrix method. Sudbury: Jones \& Bartlett; 2011.
15. Duffy ME. A research appraisal checklist for evaluating nursing research reports. Nurs Heath Care. 1985;6(10)538-47.

16. Myny D, Van Goubergen D, Gobert M, Wanderweek K, Van Hecke A, Defloor T. Non-direct patient care factors influencing nursing workload: a review of literature. J Adv Nurs. 2011;67(10):2109-29.

17. Perroca MG, Gaidzinski RR. Instrumento de Classificação de Pacientes de Perroca: teste de confiabilidade pela concordância entre avaliadores - correlação. Rev Esc Enferm USP. 2002;36(3):245-52.

18. Perroca MG, Gaidzinski RR. Avaliando a confiabilidade interavaliadores de um instrumento para classificação de pacientes - coeficiente Kappa. Rev Esc Enferm USP. 2003;37(1):72-80.

19. Andrade S, Serrano SV, Nascimento MSA, Peres SV, Costa AM, Lima RAG. The evaluation of an instrument for pediatric oncology patient classification. Rev Esc Enferm USP. 2012;46(4):816-21.

20. Perroca MG. The new version of a patient classification instrument: assessment of psychometric properties. J Adv Nurs. 2013;69(8):1862-8.

21. Perroca MG. Instrument for patient classification: users' opinions and analisys of healthcare indicators. Rev Esc Enferm USP. 2008;42(4):656-64.

22. Dini AP, Fugulin FMT, Veríssimo MLÓR, Guirardello EB. Pediatric Patient Classification System: construction and validation of care categories. Rev Esc Enferm USP. 2011;45(3):575-80.

23. Perroca MG, Gaidzinski RR. Análise da validade de constructo do instrumento de classificação de pacientes proposto por Perroca. Rev Latino Am Enfermagem. 2004;12(1):83-91.

24. Perroca MG, Ek AC. Assessing patient's care requirements: a comparison of instruments. Scand J Caring Sci. 2007;21(3):390-6.

25. Carmona LMP, Évora YDM. Grau de dependência do paciente em relação à enfermagem: análise de prontuários. Rev Latino Am Enfermagem. 2003;11(4):468-73.

26. Ohara R, Melo MRAC, Laus AM. Caracterização do perfil assistencial dos pacientes adultos de um pronto socorro. Rev Bras Enferm. 2010;63(5):749-54.

27. Brito AP, Guirardello EB. Nível de complexidade assistencial dos pacientes em uma unidade de internação. Rev Bras Enferm. 2012;65(1):92-6.

28. Carmona LMP, Évora YDM. Sistema de classificação de pacientes: aplicação de um instrumento valido. Rev Esc Enferm USP. 2002;36(1):42-9. 
29. Fonseca JP, Echer IC. Grau de dependência de pacientes em relação à assistência de enfermagem em uma unidade de internação clínica. Rev Gaúcha Enferm. 2003;24(3):346-54.

30. Laus AM, Anselmi ML. Caracterização dos pacientes internados nas unidades médicas e cirúrgicas do HCFMRP-USP, segundo grau de dependência em relação ao cuidado de enfermagem. Rev Latino Am Enfermagem. 2004;12(4):643-9.

31. Hammermüller A, Rabelo ER, Goldmeier S, Azzolin KO. Classificação de pacientes atendidos em uma unidade de hemodinâmica segundo o grau de dependência dos cuidados de enfermagem. Acta Paul Enferm. 2008;21(1):72-6.

32. Araújo VB, Perroca MG, Jericó MC. Variability in the complexity of patient's nursing care needs. Rev Latino Am Enfermagem. 2009;17(1):34-9.

33. Lima LB, Borges D, Costa S, Rabelo ER. Classification of patients according to the degree of dependence on nursing care and illness severity in a post- anesthesia care unit. Rev Latino Am Enfermagem. 2010;18(5):881-7.

34. Cucolo DF, Perroca MG. Monitoring performance indicators regarding the length of care by the nursing team. Rev Esc Enferm USP. 2010;44(2):497-503.

35. Urbanetto JS, Marco R, Carvalho SM, Creutzberg M, Oliveira KF, Magnago TBS. Grau de dependência de idosos hospitalizados conforme o sistema de classificação de pacientes. Rev Bras Enferm. 2012;65(6):950-4.

36. Oliveira RP, Laus AM. Characterization of patients in psychiatric hospitalization units according to the degree of dependence on nursing care. Rev Esc Enferm USP. 2011;45(5):1164-70.

37. Mukai HA, Jericó MC, Perroca MG. Care needs and workload required by institutionalised psychiatric patients. Rev Latino Am Enfermagem. 2013;21(1):340-7.

38. Gouveia MTO, Mendes MCS, Luz YPO, Silva GRF. Classificação de pacientes pediátricos em um Hospital de Ensino de Teresina. Rev RENE. 2010;11(n.esp):160-8.
39. Giglio MM, Martins AP, Dyniewicz AM. Análise do grau de dependência e predisposição à úlcera de pressão em pacientes de hospital universitário. Cogitare Enferm. 2007;12(1):62-8.

40. Pagliarini FC, Perroca MG. Uso de instrumento de classificação de pacientes como norteador do planejamento de alta de enfermagem Acta Paul Enferm. 2008;21(3):393-7.

41. Gaidzinski RR, Fugulin FMT, Castilho V. Dimensionamento de pessoal de enfermagem em instituições de saúde. In: Kurcgant $\mathrm{P}$, coordenadora. Gerenciamento em enfermagem. 2a ed. Rio de Janeiro: Guanabara Koogan; 2012. p.121-35.

42. Pasquali L. Psychometrics. Rev Esc Enferm USP. 2009;43(n. spe):992-9.

43. Polit DF, Beck CT, Hungler BP. Fundamentos de pesquisa em enfermagem: avaliação de evidências para a prática da enfermagem. 7a ed. Porto Alegre: Artmed; 2011.

44. Levenstam AK, Engberg IB. How to translate nursing care into costs and staffing requirements: part two in the Zebra system. J Nurs Manag. 1997;5(2): 105-14.

45. Rainio AK, Ohinmaa AE. Assessment of nursing management and utilization of nursing resources with the RAFAELA patient classification system: case study from the general wards of one central hospital. J Clin Nurs. 2005;14(6):674-84.

46. Fagerstrom L. Evidence-based human resource management: a study of nurse leaders' resource allocation. J Nurs Manag. 2009;17(4):415-25.

47. Rauhala A, Kivima M, Fagerstrom L, Elovainio M, Virtanen $M$, Vahtera J, et al. What degree of work overload is likely to cause increased sickness absenteeism among nurses? Evidence from the RAFAELA patient classification system. J Adv Nurs. 2007;57(3):286-95. 